Original Article

\title{
ANTIOXIDANT ACTIVITY AND TOTAL PHENOLIC CONTENT IN RIPE AND UNRIPE POMEGRANATE (PUNICA GRANATUM L.) FRUIT JUICE
}

\author{
MUHAMMAD AMJAD1,3*, ZOBIA ANWER ${ }^{2}$
}

${ }^{1}$ Department of Plant Breeding and Genetics, University of Agriculture Faisalabad, Pakistan, ${ }^{2}$ Department of Botany, University of Agriculture Faisalabad, Pakistan

Email: mauaf786@gmail.com

Received: 01 May 2021, Revised and Accepted: 27 Jun 2021

\section{ABSTRACT}

Objective: P. granatum L. is famous for antioxidant activity and utilized as a nourishing foodstuff. This work aimed to recognize the antioxidant activity and TPC in extracts of ripe and unripe fruit juice.

Methods: Competency of the solvents (water, methanol, acetone, chloroform, ethanol) were evaluated by analyzing extracts of ripe and unripe $P$. granatum L. fruit juice for TPC and DPPH* scavenging assay. FTC method measured the level of peroxides.

Results: In TPC extraction, the water solvent showed greater potential in both ripe (10.5 \pm 2.1$)$ and unripe fruit juice (4.1 \pm 0.3$)$ amongst all other solvents. Ethanol and water solvent showed the highest value of $\mathrm{DPPH}^{*}$ scavenging activity $(96 \% \pm 6.81$ and $72 \% \pm 3.50$ respectively) in ripe and unripe fruit juice. According to absorbance of DPPH radicals, the water solvent showed the highest antioxidant potential in ripe fruit juice $(86 \% \pm 6.78)$ like chloroform solvent in unripe fruit juice $(14 \% \pm 0.03)$. Unripe fruit juice showed lowest level of absorbance of DPPH radicals and highest antioxidant potential amid all solvents. In FTC method, unripe fruit juice showed the highest antioxidant activity and low amount of peroxides for consecutively seven days.

Conclusion: Ripe fruit juice showed the highest TPC and unripe fruit juice showed the maximum value of antioxidant potential. P. granatum L. provides an excellent supply of antioxidant activity and used in pharmaceutical and food industry.

Keywords: Antioxidant ability, DPPH scavenging assay, TPC, P. granatum L., Peroxides

(C) 2021 The Authors. Published by Innovare Academic Sciences Pvt Ltd. This is an open access article under the CC BY license (https://creativecommons.org/licenses/by/4.0/) DOI: https://dx.doi.org/10.22159/ijcpr.2021v13i4.42745 Journal homepage: https://innovareacademics.in/journals/index.php/ijcpr

\section{INTRODUCTION}

P. granatum L. belongs to Lythraceae family as a deciduous shrub. It is a local fruit of Iran and now it is grown all over the world as fruit and ornamental plant. It is a good supplier of vitamin K, E, C, A as well as folate, minerals, carbohydrates, fat and fiber [1]. Fruit juice is sweet but sometimes has sour taste due to the presence of ellagitannins acid
[2]. Fruit have countless biological activities owing to the presence of active components like flavonoids, ascorbic acid, cynogenic glucosidase, papine and chymopepine etc. In latest research, $P$. granatum C. papaya L. extracts has been reported as a strong antidengue tonic that is supportive in recuperating the white blood cell hastily after illness [3]. In Pakistan, Balochistan considers the orchards of P. granatum L. and also grow in Punjab and KPK at a small scale.

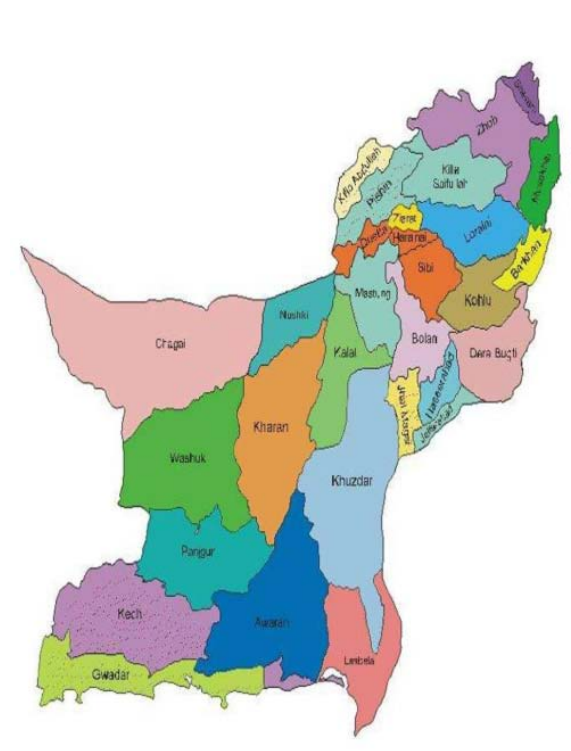

Balochistan

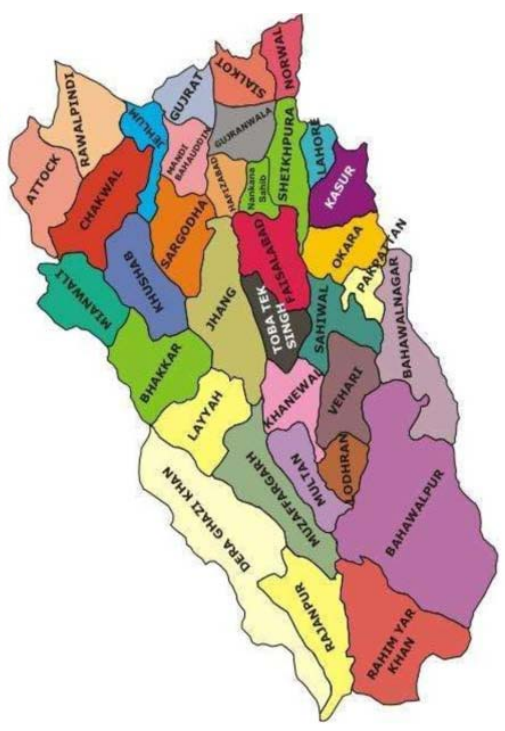

Punjab

Fig. 1: Orchads of pomegranate in Punjab and Balochistan 
Reactive oxygen species and free radicals are constantly formed in the individual body during ordinary liver functions, cellular metabolism and mitochondrial respiratory system [4]. The function of reactive oxygen species and free radicals is eminent in human being after damaging the biomolecules (lipids, DNA, proteins etc.). Oxidative stress has been reported as an elementary mechanism for the development of manifold health disorders, infections and illnesses like hemorrhage, respiratory problems, ulcers and dysentery etc. [5]. The current experiment was designed to determine the consequence of solvents (water, ethanol, methanol, chloroform and acetone) after extraction of TPC and antioxidant potential of ripe and unripe P. granatum L. fruit juice. These investigations will be helpful in securing maximum benefits associated with bioactive compounds present in P. granatum L.

\section{MATERIALS AND METHODS}

\section{Fruit collection}

P. granatum L. (genotype name Golden) was collected from Local market of Bahawalpur, Punjab.

\section{Preparation of P. granatum L. fruit juice extract}

Samples washed several time with tap water. The edible portion (unripe and ripe) peeled out, cut into pieces and then grinded. After this, took $10 \mathrm{~g}$ papaya (ripe, unripe) from paste and dissolved in different solvents (methanol, ethanol, acetone, chloroform, water). After this shake, put into orbital shaker at 200rpm for $2 \mathrm{~h}$ and centrifuge the mixture in centrifuge machine at $1000 \mathrm{rpm}$ for $15 \mathrm{~min}$. The filter paper (Whatman No. 4) was used for filtration of mixture.

\section{Quantification assay}

\section{Estimation of total phenolic content (TPC)}

Estimation of TPC evaluated by Folin-Ciocalteu reagent assay [6]. The reaction mixture was prepared by mixing $2 \mathrm{mg}$ of papaya extract and $100 \mu \mathrm{L}$ of freshly prepared $0.5 \mathrm{ml}$ Folin-Ciocalteu reagent. The primed mixtures were permitted to locate in dark for $15 \mathrm{~min}$ followed by the addition of $2.5 \mathrm{ml}$ sodium carbonate $(6 \%)$ and the resultant mixture was incubated in dark for $30 \mathrm{~min}$. The absorbance was recorded at $725 \mathrm{~nm}$ by UV visible spectrophotometer (CECIL, Milton Technical Centre, Cambridge UK). The results were calculated by standard ascorbic acid [7].

\section{Determination of antioxidant potential}

\section{DPPH radical scavenging assay}

The capability of the extracts to scavenge 2, 2-diphenyl-1picrylhydrazyl (DPPH) radicals were calculated by reported method [8]. $3.9 \mathrm{ml}$ of methanolic solution of DPPH radical $(25 \mathrm{mg} / \mathrm{ml})$ added in the diluted papaya extract $(0.2 \mathrm{ml})$. The mixture left in the dark for $30 \mathrm{~min}$ after shaking. The mixture's absorbance was recorded at $500 \mathrm{~nm}$ in opposition to absolute methanol without DPPH •. The outcomes were recorded in percentage which was used to evaluate the radical scavenging potential of $C$. papaya fruit extracts.

\section{FTC method (Ferric thiocyanate)}

Hydro peroxides produced when linoleic acid and reaction mixture was combined [9]. $2 \mathrm{ml}$ of sample (methanol extract) $+2.5 \%$ linolenic acid in $99.8 \%$ ethanol took $2.05 \mathrm{ml}+4 \mathrm{ml}$ of $0.05 \mathrm{~mol}$. After this, 1.95 $\mathrm{ml}$ of water added in the flask and placed in a rotary incubator $\left(150 \mathrm{r} / \mathrm{min}\right.$ at $\left.40{ }^{\circ} \mathrm{C}\right)$ in a dark place. To calculate the antioxidant value, $0.1 \mathrm{ml}$ of above sample mixture added in the test tube with added $9.7 \mathrm{ml}$ of $75 \%$ ethanol $+0.1 \mathrm{ml}$ of $30 \%$ ammonium thiocyanate and $0.1 \mathrm{ml}$ of $2 \times 10^{2} \mathrm{~mol} / \mathrm{l} \mathrm{FeCl}_{2}$ in $3.5 \% \mathrm{HCl}^{\mathrm{FeCl}} \mathrm{Fel}_{2}$ added in the reaction mixture and absorbance was recorded at $500 \mathrm{~nm}$. Measurements were recorded after every $24 \mathrm{~h}$ until the absorbance of the control and blank soln. reached its maximum [10].

- Sample preparation: Took $0.5 \mathrm{ml}$ of sample (ripe, unripe, vitamin E) then added $0.5 \mathrm{ml}$ linoleic acid, $0.5 \mathrm{ml}$ water and $1 \mathrm{ml}$ phosphate buffer. After this, covered and placed into oven at $40{ }^{\circ} \mathrm{C}$. Took $0.1 \mathrm{ml}$ from the above soln. then added $9.7 \mathrm{ml}$ of $75 \%$ ethanol, $0.1 \mathrm{ml}$ ammonium thiocyanate and $0.1 \mathrm{ml}$ of $\mathrm{FeCl}_{2}$ in $\mathrm{HCl}$ solution.

- Control: $1 \mathrm{ml}$ buffer, $0.5 \mathrm{ml}$ water placed into oven at $40{ }^{\circ} \mathrm{C}$. After this, took $0.1 \mathrm{ml}$ of above soln then added $9.7 \mathrm{ml}$ of $75 \%$ ethanol 0.1 $\mathrm{ml}$ ammonium thiocyanate and $0.1 \mathrm{ml}$ of $\mathrm{FeCl}_{2}$ in $\mathrm{HCl}$ soln.

- Blank: Add $0.5 \mathrm{ml}$ of methanol, $0.5 \mathrm{ml}$ of water, $1 \mathrm{ml}$ buffer and a then similar process of the above [11].

\section{RESULTS AND DISCUSSION}

\section{Determination of total phenolic contents (TPC)}

Water showed greater potential among all other solvents. All these observations proposed that phenolic compounds are highly polar in polar solvents. The range of polarity of solvents in ripe and unripe papaya fruit is Methanol $<$ Chloroform $<$ Ethanol $<$ Acetone $<$ Water. The polarity of methanol solvent in unripe papaya fruit is greater than ripe papaya fruit. Phenolic constituents are also called secondary metabolites, which are familiar due to free radical scavenging potential [12]. The TPC in ripe fruit was highest than the unripe fruit [13]. Phenolic contents with tannins, anthocyanin and flavonoids consider the main antioxidant phytochemical because of free radical scavenging [14]. The water has a high ability to soluble a larger fraction of the phenolic components present in papaya [15]. Antioxidant potential and TPC had a direct relationship with each other [16].

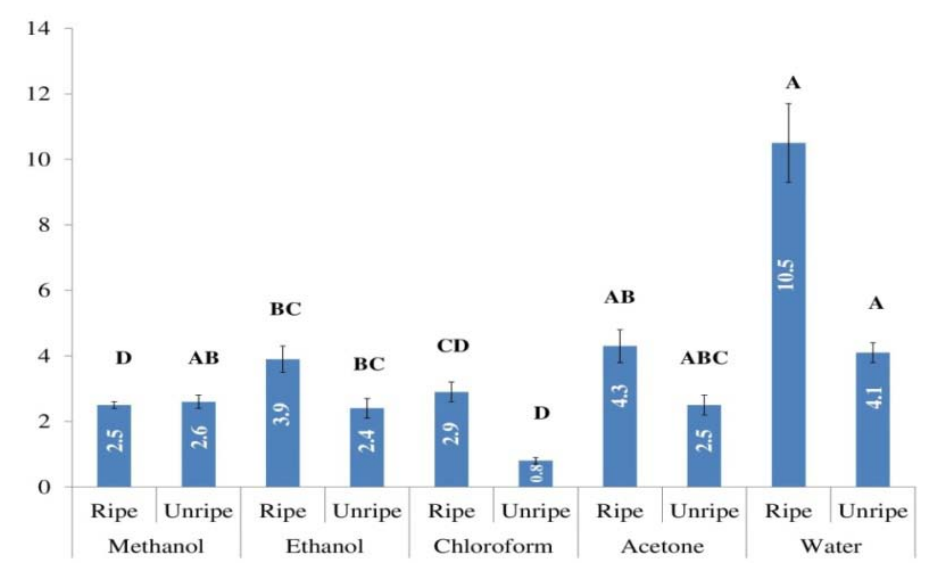

Fig. 2: Comparison of total phenolic content $(\mu \mathrm{g} / \mathrm{g})$ in different solvents

\section{Estimation of DPPH scavenging activity}

The DPPH scavenging activity highest in ripe fruit as compared to unripe fruit in all solvents. Ethanol solvent showed the highest DPPH radicals scavenging activity in ripe fruit and water solvent showed the best result in unripe fruit juice as compared to all other solvents. In ripe fruit extraction, all solvents showed the significance difference unlike unripe fruit extraction. The order of solvent 
potential in ripe fruit juice was Ethanol>Chloroform $>$ Acetone $>$ Methanol $>$ Water and in unripe fruit was Water $>$ Ethanol $>$ Methanol $>$ Acetone $>$ Chloroform. Water solvent showed the highest capacity as antioxidant in ripe fruit juice like chloroform solvent in unripe fruit juice, because antioxidant activity decreases the absorbance of DPPH radicals. The colour of end product in the reaction was changed due to the donation of hydrogen [17]. That; s why, the DPPH radicals showed stability at room temperature [18]. Odd electron in $\mathrm{DPPH}^{*}$ given a strong absorption [19].

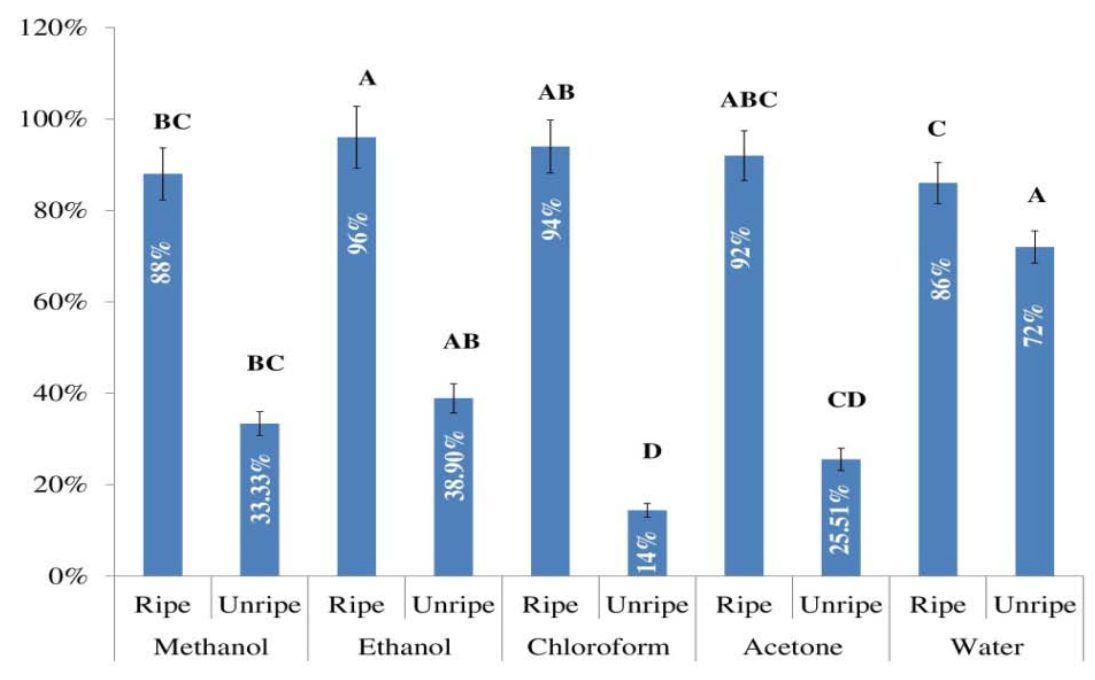

Fig. 3: Comparison of radical DPPH scavenging potential (\%) among different solvents

\section{FTC method (ferric thiocyanate)}

The level of peroxides recognize by FTC method at the beginning stage of lipid oxidation. All extracts showed the significance result for consecutively seven days. The highest concentration of peroxides showed by blank and ripe fruit extract showed the lowest peroxides potential. The lowest amount of peroxides showed the highest antioxidant capacity. In term of antioxidant activity, the unripe fruit showed highest antioxidant capacity consecutively seven days in all extracts. Absorbance rate reached at the maximum level from $1^{\text {st }}$ to $6^{\text {th }}$ day and eventually start to drop from $7^{\text {th }}$ day. The large amount of peroxide decreased the antioxidant capacity [20].

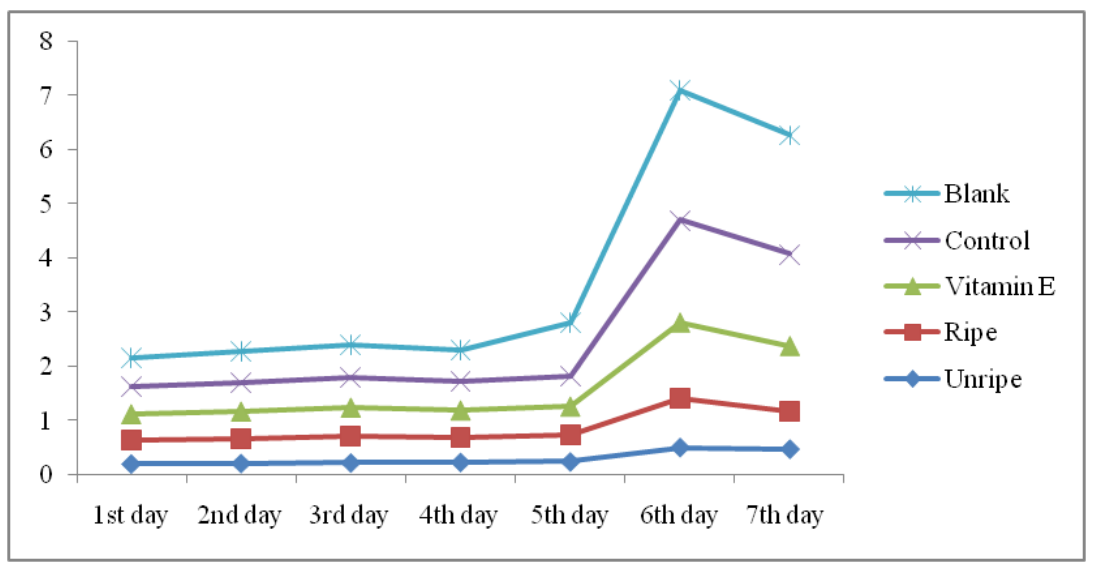

Fig. 4: Amount of peroxides in consecutive seven days

\section{CONCLUSION}

$P$. granatum L. fruit juice is the principal source of phenolic compounds. It also called nutraceutical fruit due to presence of vitamins, enzymes, carbohydrates and bioactive compounds. Ripe fruits juice contained highest total phenolic contents and unripe fruits juice have highest antioxidant potential. According to absorbance of DPPH* $^{*}$ scavenging assay, chloroform solvent showed maximum antioxidant potential in unripe fruit juice like water solvent in ripe fruit juice. Unripe fruit juice showed the lowest amount of peroxides and the highest potential as antioxidant activity. Unripe fruit juice showed maximum strength like antioxidant potential in both $\mathrm{DPPH}^{*}$ scavenging assay and FTC method. It can be used for cure of much disease like blood pressure, constipation, warts and cancer etc.

\section{ABBREVIATION}

TPC, Total Phenolic Content; DPPH*, 2-2 diphenyl-1-picrylhydrazyl radical; FTC, Ferric thiocyanate.

\section{FUNDING}

Nil

\section{AUTHORS CONTRIBUTIONS}

All the authors have contributed equally.

\section{CONFLICT OF INTERESTS}

Declared none 


\section{REFERENCES}

1. Hernandez F, Melgarejo P, Tomas Barberan FA, Artes F. Evolution of juice anthocyanins during ripening of new selected pomegranate (Punica granatum) clones. Eur Food Res Technol 1999;210:39-42.

2. Gomez Caravaca AM, Verardo V, Toselli M, Segura Carretero A, Fernandez Gutierrez A, Caboni MF. Determination of the major phenolic compounds in pomegranate juices by HPLC-DAD-ESI-MS. J Agric Food Chem 2013;61:5328-37.

3. Ahmad N, Fazal H, Ayaz M, Abbasi BH, Mohammad I, Fazal L. Dengue fever treatment with Carica papaya leaves extracts. Asian Pac J Trop Biomed 2011;1:330-4.

4. Iqbal S, Younas U, Chan KW, Zia-ul-Haq M, Ismail M. Chemical composition of Artemisia annua L. leaves and antioxidant potential of extracts as a function of extraction solvents. Molecules 2012;17:6020-32.

5. Al-Muammar MN, Fozia K. Obesity: the preventive role of the pomegranate (Punica granatum). Nutrition 2012;28:595-604.

6. Oad FC, Lakho AA, Khan A, Ansari AH, Sheikh FM, Khail MUU. Economics of Papaya in Malir, District Karachi, Pakistan. Int J Agric Biol 2001;3:477-81.

7. Annegowda HV, Mordi MN, Ramanathan S, Hamdan MR, Mansor SM. Effect of extraction techniques on phenolic content, antioxidant and antimicrobial activity of Bauhinia purpurea: HPTLC determination of antioxidants. Food Anal Methods 2012;5:226-33

8. Ding WJ, Hasegawa T, Peng D, Hosaka H, Seko Y. Preliminary investigation on the cytotoxicity of tellurite to cultured HeLa cells. J Trace Elem Med Biol 2002;16:99-102.

9. Wijekoon MMJO, Bhat R, Karim AA. Effect of extraction solvents on the phenolic compounds and antioxidant activities of bunga kantan (Etlingera elatior J.) inflorescence. J Food Compost Anal 2001;24:615-9.
10. Lee JY, Hwang WI, Lim ST. Antioxidant and anticancer activities of organic extracts from Platycodon grandiflorum A. de candolle roots. J Ethnopharmacol 2004;93:409-15.

11. Zhou K, Laux JJ, Yu LL. Comparison of swiss red wheat grain and fractions for their antioxidant properties. J Agric Food Chem 2004;52:1118-23.

12. Gai QY, Jiao J, Mu PS, Wang W, Luo M, Li CY, et al. Microwaveassisted aqueous enzymatic extraction of oil from Isatis indigotica seeds and its evaluation of physicochemical properties, fatty acid compositions and antioxidant activities. Ind Crops Prod 2013;45:303-11.

13. Sultana B, Anwar F, Ashraf M. Effect of extraction solvent/technique on the antioxidant activity of selected medicinal plant extracts. Molecules 2009;14:2167-80.

14. Elfalleh W, Tlili N, Nisari N, Yahia Y. Antioxidant capacities of phenolic compounds and tocopherols from Tunisian pomegranate (Punica granatum) fruits. J Food Sci 2011;76:C707-C713.

15. Jayaprakasha GK, B Girennavar B, Patil BS. Antioxidant capacity of pummelo and navel oranges: extraction efficiency of solvents in sequence. LWT Food Sci Technol 2008;41:376-84

16. Yang J, Liu RH, Halim L. Antioxidant antiprolifera activities of common edible nut seeds. LWT Food Sci Technol 2009;42:1-8.

17. Mosmann T. Rapid colorimetric assay for cellular growth and survival: application to proliferation and cytotoxicity assays. J Immunol Methods 1983;65:55-63.

18. Hemwimon S, Pavasant P, Shotipruk A. Microwave-assisted extraction of antioxidative anthraquinones from roots of Morinda citrifolia. Sep Purif Technol 2007;54:44-50.

19. Azizah AH, Ruslawati NMN, Tee TS. Extraction and characterization of antioxidant from cocoa by-product. Food Chem 1999;64:199-202.

20. Leng B, Liu XD, Chen QX. Inhibitory effects of an anticancer peptide from Mercenariaon the BGC-823 cells and several enzymes. FEBS Lett 2005;579:1187-90. 